This paper was published in Asian Journal of Political Science, Vol. 13, No. 1 (June 2005): 1-21. This is a final version prior to the proof.

\title{
Contrasts in China and Soviet Reform: Sub-national and National Causes
}

\author{
HONGYI HARRY LAI
}

Why did reform in China and the former Soviet Union produce drastically different outcomes? Why did some provinces in China embrace faster economic reform than others? This article argues that the state sector and reform initiatives in the sub-national units, reform strategies, entrenchment and maturation of central planning, the size of the defence industry, policy choice and the historical context help explain the differences in Soviet and Chinese reform courses and outcomes. A predominant state sector in the former Soviet republics had stifled local reform initiatives. Gorbachev resorted to democratisation in order to unbolt the gate for popular support for marketisation, yet resulting in the breakup of the Soviet Union and destabilising the economy. In China, some provinces had sizable non-state sectors and were inclined to push forth marketization. Reform resulted in expanding non-state sectors, generating high growth and encouraging the regime to maintain its monopoly of power. China's reform also benefited from a yet-to-be-entrenched and rudimentary central planning, a small defence sector, popular backlash against past policies, and reformist pragmatic strategy.

\section{Introduction}

Two puzzles have generated heated debates in the studies of reform in China and the former Soviet Union. The first puzzle is a sharp contrast in the approaches and outcomes of reform in the two largest communist countries, namely, China and the Soviet Union. Since 1978, Chinese leaders have embarked on economic reform without loosening political control. China has been experiencing the longest and most rapid industrialisation in its modern history. On the other hand, Soviet leaders moved decisively to open up their political system and to decentralise political power. In the following years, the Soviet Union collapsed and economic depression ensued. The second puzzle relates to the variation in reforms in China's provinces. Between 1978 and 1994, during the first decade and a half of Chinese reform, some provinces pressed for reform while others did so hardly at all.

Two sets of questions thus arise. First, why did reform in China and the former Soviet Union go through such drastically different courses? How did reform paths in the countries help generate the contrasting outcomes? Second, why were some provinces in China more ready to embrace economic reform than others? As to be explained, these two puzzles can be solved by investigating national and sub-national factors that led to divergences of reform in the countries.

A number of scholars have commented on this China-Soviet contrast in reform. Two contending approaches have caught much attention. Incrementalists argued that China's gradualist reform successfully overcame economic uncertainties during transition, allowed time for institutions to take root, and built political support for reform. ${ }^{1}$ On the 
other hand, advocates for radical reform counter-argued that economic reform worked only when it came in a package and was implemented all at once. Furthermore, the political and economic establishments might only want partial reform so that they could continue to collect high rents from resources they controlled. ${ }^{2}$ Democratisation could introduce popular support for reform and overcome resistance by these special interests to reform. ${ }^{3}$ These scholars blamed the Soviet Union for failing to carry out necessary economic reforms.

Scholars also explained the China-Soviet contrast in terms of their structural or institutional differences. Pei and Huang postulated that China's state socialism was less developed than that in Eastern Europe and the former Soviet Union. As a result, the former was more flexible and responsive to partial reform. ${ }^{4}$ Sachs and Woo, on the other hand, argued that a large state sector in the former Soviet Union and Eastern Europe precluded smooth and fruitful gradual reform for heavily subsidised employees of state firms refused to move to more dynamic non-state ones. They postulated that a small state sector, a largely rural population, and small heavy industry contributed to the success of reform in China. ${ }^{5}$ Aslund argued that communist ideology, party, economy and bureaucracy were more entrenched and harder to reform in the Soviet Union than in China. ${ }^{6}$ Finally, Solnick argued while decentralisation in the Soviet Union triggered a bank run by local agents to seize organisational assets and property rights, the central government in China was ready to defend its reputation and prevent any bank run. ${ }^{7}$ Similarly, Treisman argued that political decentralisation was fruitful in homogeneous China but turned out to be disastrous in the divided Soviet Union and Yugoslavia. ${ }^{8}$

The above discussion has provided us with useful insights into possible causes for the China-Soviet contrast. As suggested, a small state sector, a backward command economy, and reform strategies may play a critical role in divergent reforms in excommunist countries. A large state sector would employ more employees. Thorough economic reforms would drive many state-owned enterprises (SOEs) into bankruptcy, resulting in many workers losing their jobs, and making a large bureaucracy supervising these enterprises irrelevant. Therefore, both SOE employees and bureaucrats would resist reform in order to protect their jobs.

It still has yet to be shown, however, how the size of the state sector and resistance against reform led to differing reform strategies and helped to account for the differing reform and contrasting outcomes in the Soviet Union and China. For example, what role did the state sector play in sluggish economic reform and rapid political reform in the former Soviet Union in the 1980s? Did the size of the state sector have anything to do with China's smooth marketisation and sluggish political reform? Is there any logical link between the state sector on the one hand and the disruptive Soviet decentralisation and orderly Chinese decentralisation on the other? Are there other important factors that led the two nations down the divergent paths of reform? These questions beg answers.

I will demonstrate in this article that two sets of factors help to explain the ChinaSoviet contrasts in reform. The first set is the size of the state sector and the inclination for reform at the sub-national level as well as reform strategies adopted by top leaders of the nation. The former Soviet republics and the Soviet Union as a whole had a predominantly large state sector that would go under at market competition. The large state sector had stifled local initiatives for marketisation. Frustrated by sluggish economic reforms, Gorbachev opened up the political system in order to reduce 
resistance to reform. This strategy, however, resulted in independent movements in the republics and the breakup of the USSR, destabilising the economy. In China, some provinces had sizable non-state sectors. When top leaders called for marketisation, these provinces were quick to embrace it in order to expand dynamic non-state sectors and generate growth. As successful economic reform can take off without democratisation and alleviate popular distrust of the regime, the Chinese Communist Party (CCP) sees fewer imperatives for giving up its monopoly of power. The different size of the state sectors and presence or absence of political decentralisation thus help explain the contrast in China and Soviet reform. Soviet and China's reform strategies are depicted in Diagram 1, where the arrow represents the sequence of reform steps and the plus sign stands for simultaneous occurrence.

\section{Diagram 1. Approaches to Reform at Sub-national Level since the Mid-1980s}

USSR: Large state sector $\rightarrow$ Sluggish economic reform $\rightarrow$ Democratisation (political decentralisation) $\rightarrow$ Breakup of the nation + economic decline

China: Small state sector $\rightarrow$ Smooth economic reform (economic decentralisation) $\rightarrow$ Rapid economic growth + no political reform + political unity

A second set of factors includes China's less entrenched and more rudimentary central planning, a smaller defence sector, stronger popular backlash against past economic policies at the onset of reform, and more pragmatic and incremental reform strategy. Because of these factors, China's economic reform was less costly, more sustainable and productive, and more acceptable to central bureaucrats and especially the public. The remainder of the article will illustrate contrasts in Chinese and Soviet reform, evaluate the first set of factors in detail, and then discuss the role of the second set.

\section{Contrast in Chinese and Soviet/Russian Reforms}

Both China and the Soviet Union launched marketisation programmes in the late 1980s and the 1990s. The Soviet Union also embarked on democratisation. However, the two reforms end with starkly contrasting outcomes. Economically, China's economy experienced phenomenal growth in the past two-and-half decades while the economy of the most of the former Soviet republics suffered a collapse in the 1990s. Some of the former republics have just started to recover in the recent years. Figure 1 illustrates the drastic economic contrast in China and Russia, the largest former Soviet republic in the 1990s. By 1999 China's GDP was 2.4 times that in 1990, representing a high growth of $140 \%$. In contrast, Russia's GDP in 1999 was only $54.6 \%$ that in 1990 , registering a steep decline by $45 \%$.

Politically, the two reforms also ended differently. In 1991, the Soviet Union broke up into 13 independent states, whereas mainland China remained unified. Therefore, it could be said that China's economic reform is by and large very successful, whereas the Soviet approach to marketisation had encountered severe setbacks. 


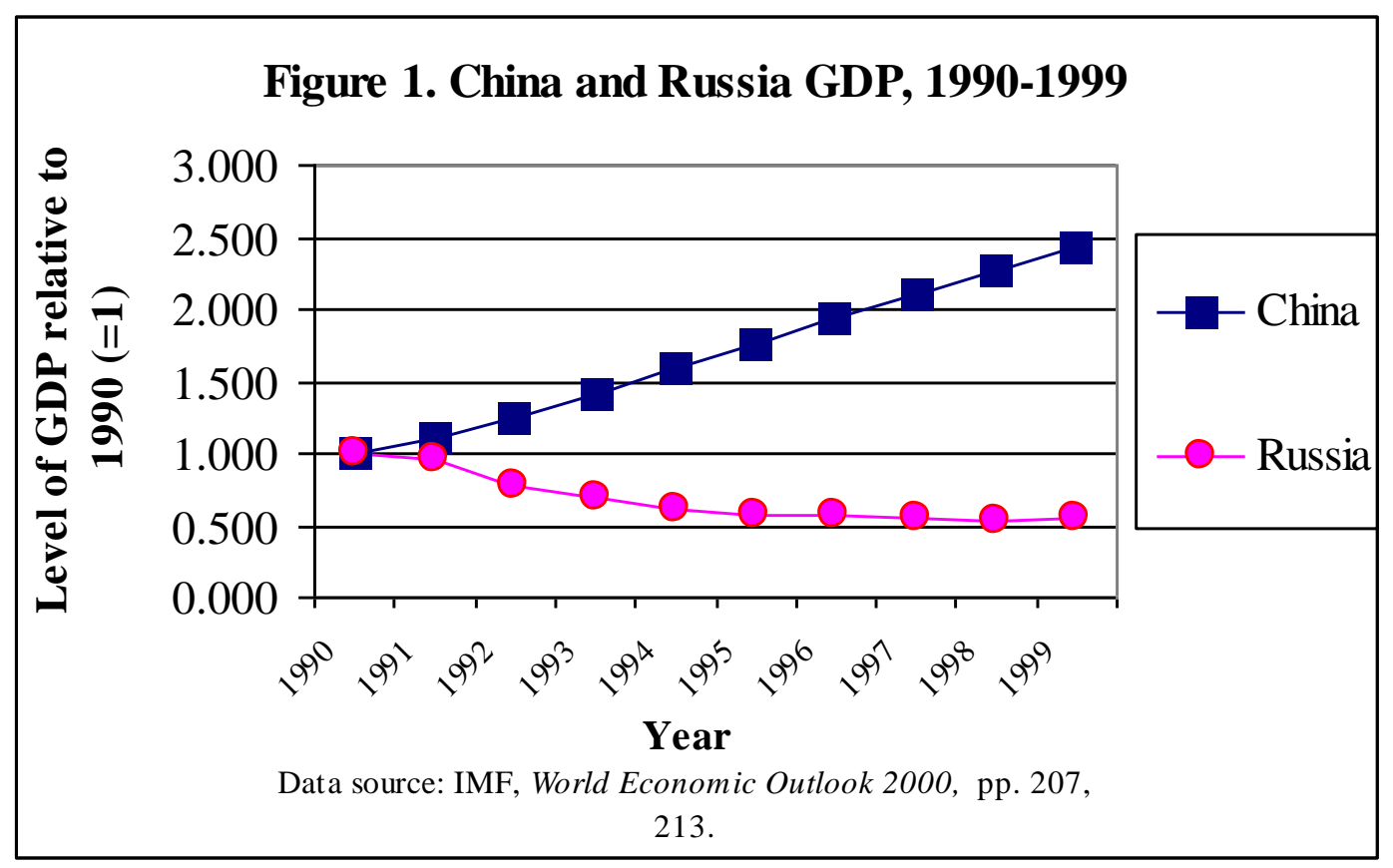

What is the explanation for the stark contrast in these two reforms? The first set of causes is the different size of the state sector and consequential differing reform strategies in these countries. In the former Soviet Union and its republics the state sector took up an overwhelming share of total and urban employment prior to perestroika. The state sector accounted for $88 \%$ of total labour versus China's $24 \%$; $96 \%$ of urban labour force versus China's 78\%; and 79-99\% of urban employment in the former Soviet Republics, compared to $58-93 \%$ in China's provinces (Table 1). With marketisation millions of employees in a heavily subsidised state sector as well as a large bureaucracy overseeing the state would suffer losses in income and even jobs. Therefore, resistance to economic reform was very strong in the former Soviet republics as well as the central bureaucracy.

Even though Gorbachev had tried to implement perestroika (economic reform) during the 1985-87 period, he encountered strong opposition and did not succeed. The resistance came from the powerful yet conservative coalition between top leaders and the Central Committee of the Communist Party, ${ }^{9}$ bureaucrats at various levels who clumsily managed the economy, ${ }^{10}$ as well as workers who were worried about losses in welfare. ${ }^{11}$ In other words, "a coalition of workers, managers, and bureaucrats in the declining sectors succeed in frustrating the needed adjustments". 12

As a result of the resistance and the long-standing tradition of central planning, the actual economic reforms that bureaucrats and official analysts favoured and implemented were very timid. These reforms left intact the fundamentals of the command economy and strained central-local relations. ${ }^{13}$ Even after adjustment prices remained distorted, sending wrong signals to consumers and producers; enterprises were still subordinated to the supervision of bureaucracies. ${ }^{14}$ Central ministries controlled fiscal revenue and major industries. The republics and localities were assigned daunting tasks to finance public services with limited resources and were also given limited room to exercise their 
economic initiatives. These measures exacerbated central-local fissures and economic problems. $^{15}$

Table 1: State Sector in China and the Former Soviet Union

\begin{tabular}{ccccc}
\hline Indicators & $\begin{array}{c}\text { China } \\
(1978)\end{array}$ & $\begin{array}{c}\text { USSR } \\
(1988)\end{array}$ & $\begin{array}{l}\text { China's } \\
\text { Provinces }\end{array}$ & $\begin{array}{l}\text { Former Soviet } \\
\text { Republic }\end{array}$ \\
\hline $\begin{array}{c}\text { Share of the state sector in } \\
\text { total employment (\%) }\end{array}$ & 24 & 88 & $12-53$ & $63-93$ \\
$\begin{array}{c}\text { Share of the state sector in } \\
\text { urban employment (\%) }\end{array}$ & 78 & 96 & $58-93$ & $\begin{array}{l}79-99 \\
\text { (estimate) }\end{array}$
\end{tabular}

Source: SSB, Quanguo Gesheng, Zizhiqu, Zhixiashi Lishi Tongji Ziliao Huibian; IMF et al, A Study of the Soviet Economy, p. 220; and CIA, The World Factbook 1999 (at http://www.odci.gov/ cia/publications /factbook/country.html).

Setbacks in economic reform and frustration at economic conditions prompted Gorbachev to change his reform strategy in order to overcome the opposition to reform. He emphasised glasnost and demokratizatsiya after 1986. Through media openness he wanted to expose opposition from the nomenklatura to reform and generate popular backlash at the nomenklatura. ${ }^{16}$ Through competitive election, Gorbachev aimed to remove conservative officials from powerful posts. ${ }^{17} \mathrm{He}$ decentralised political power by using competitive election to choose deputies at all levels and allowing the legislature to oversee the executive. ${ }^{18}$

The two regression formulae in Table 2 not only support this line of explanation of the Soviet reform strategy, but also shed light on the Soviet reform process. Formula 1 suggests that the former Soviet republics with a larger state sector in 1988 speeded up democratisation, and as a result, had a higher rating of political freedom during the 199394 period. In the data employed in the analysis, the political freedom of Soviet republics was ranked from 1 to 7 . The formula implies that a $50 \%$ gap in the share of the state sector in total labour force could account for a 6.5 difference in the ranking of freedom, i.e., almost the difference between the most unfree and freest of the regimes. Formula 2 suggests that the former Soviet republics which speeded up democratisation implemented bolder economic reform in the later years. Formula 2 also implies that a 7-point gap in the freedom ranking could account for a 14-point difference in the ranking of economic reform, i.e., a virtual difference between the most and the least liberal reforms (the scale of economic reform has 15 points). 


\section{Table 2: Reforms in Soviet Republics (Standard errors in parentheses)}

Formula 1. Regression of political freedom rating (1 to 7) in 1993-94 on the share of the state sector in employment in 1988 in former Soviet Republics

\section{FREEDOM $=15.07+$ 12.97 STATESECTOR}

(Adjusted R square: 0.41, significance of F: 0.02)

Formula 2. Regression of economic reform (1 to 15) in 1996 on political freedom rating in 1993-94 in former Soviet Republics

\section{ECONREFORM $=16.23+2.05$ FREEDOM}

(Adjusted R square: 0.60, significance of F: 0.003)

Notes: The formulae use data from the following 11 former Soviet republics-- Azerbaijan, Byelorussian, Estonia, Kazakhstan, Kyrgyzstan, Latvia, Lithuania, Russia, Turkmenistan, Ukraine, and Uzbekistan. The data on political repression comes from Freedom-House rating of political repression. The original rating from 1 to 7 is transformed from 7 to 1 . For example, a repression rating of 1 is transformed into freedom rating of 7.

Source: Refer to Table 1; Freedom House, Freedom in the World: The Annual Survey of Political Rights and Civil Liberties, 1993-94 (New York: Freedom House, 1994); Freedom House, World Survey of Economic Freedom, 1995-96: A Freedom House Study (New York: Freedom House, 1996).

Political reform thus changed the dynamics of economic reform in the Soviet republics. As the former Soviet republics became democratic, the public could vote on two options of reform. The first choice was partial economic reform, which would only create prolonged suffering for the populace and could benefit only groups with political connections. The other choice was fast and comprehensive reform. The public opted for faster economic reform. Empirical analyses also confirm this argument that Eastern European countries and former Soviet republics that had speeded up political liberalisation had experienced faster economic reform. ${ }^{19}$

Political reform, however, eroded central political control over localities in the Soviet Union. Russians accounted for merely $51 \%$ of the population in the Soviet Union in 1991 (Table 3), and a minority of the population in many republics. Gorbachev also failed to incorporate regional representatives in the centre. ${ }^{20}$ The Soviet sub-national elites were structured largely along ethnic line. In the wake of democratisation and political decentralisation, ethnic cadres turned into political entrepreneurs, advanced ethnofederalism and claimed independence from the centre. Gorbachev's reluctance to suppress also reinforced the determination of separatists. ${ }^{21}$ In December 1991, the presidents of Russia, Belarus, and Ukraine dealt a fatal blow to the Soviet Union by signing the Belovezhskaya Pushcha agreement that established the Commonwealth of Independent States.

Gorbachev's reform strategy proved to be disastrous. Regional separatism generated economic instability. Hasty changes in policies and lack of central supervision bred poor reform management and encouraged plundering of public assets, corruption and poor 
decisions, resulting in economic disorder. ${ }^{22}$ The collapse of the Soviet Union led to a severe disruption in trade, a drastic fall in outputs, and a rise in external debts. ${ }^{23}$

In contrast, the state sector was much smaller in China, permitting a smooth start of reform in some provinces. In addition, economic, rather than political power has been decentralised in China, no democratisation has occurred, and the Han is the majority of the population in most provinces. National unity and stability is thus maintained.

China benefited from a Han overwhelming majority $(92.2 \%)$ in the population and most of its provinces (Table 3). Only in two provinces, i.e., Tibet and Xinjiang, the Han accounted for less than $50 \%$ of the population. Although separatist movements in the two provinces pose challenges for the state, both provinces are subject to the tight and centralised control of the state. $^{24}$

Furthermore, as Huang had suggested, the central government in China has retained considerable political power. $^{25}$ Through the control of provincial-level nonmenklatura the central Party continues to appoint provincial leaders and supervise and encourage their reform efforts. Calls for democratisation in the Tiananmen Movement in 1989 in the wake of economic stresses were suppressed by force. Nevertheless, in 1992, China

Table 3: Ethnicities, Freedom, and Reform in China and the Former Soviet Union

\begin{tabular}{ccc}
\hline \multicolumn{1}{c}{ Indicators } & $\begin{array}{c}\text { China } \\
(1978)\end{array}$ & \multicolumn{1}{c}{$\begin{array}{c}\text { USSR } \\
(1988)\end{array}$} \\
\hline $\begin{array}{c}\text { Share of the largest ethnic } \\
\text { group in the population (\%) }\end{array}$ & $\begin{array}{c}92.2 \\
(1982)\end{array}$ & 51 \\
$\begin{array}{c}\text { Political freedom rating of the } \\
\text { 1990- 1991 period (1 to 7) }\end{array}$ & 1 & 3.5 \\
Reforms and outcomes & $\begin{array}{l}\text { No political opening; } \\
\text { successful economic reform } \\
\text { and economic } \\
\text { decentralisation }\end{array}$ & $\begin{array}{l}\text { Political opening and } \\
\text { decentralisation; ineffective } \\
\text { economic reforms; breakup of the } \\
\text { USSR; instability and conflict }\end{array}$ \\
\hline
\end{tabular}

Source: Refer to Table 1. The data on political repression comes from Freedom-House rating of political repression. The original rating from 1 to 7 is transformed from 7 to 1 . For example, a repression rating of 1 is transformed into freedom rating of 7 .

renewed economic liberalisation. With high growth and political stability the regime has been able to justify and sustain its reform course.

China's above reform path can work also largely because China's provinces had a much smaller state sector than the Soviet republics at the beginning of the reform (Table 1), facilitating economic liberalisation. In 1978, when China's economic reforms started, the state sector employed only $24 \%$ of total labour force in most of the Chinese provinces, and $58-77 \%$ of the urban labour force in eight eastern provinces. ${ }^{26}$ In contrast, the non-state sectors accounted for $76 \%$ of the nation's labour force (including rural labour) and $23 \%-42 \%$ of urban labour in eight coastal provinces. Thus, the state sector 
was a small provider of employment nationwide in China than in the Soviet Union. In several provinces, with steady expansion a few years after the reform, non-state sectors could grow to half of the industrial output and surpass the state sector. With firm support from national reformists such as Deng Xiaoping, under pressure from a considerable nonstate industrial sector, and eager to reap economic benefits of the larger and dynamic non-state sectors, a number of provinces would thus view reform favorably. Reform initiatives would have a greater chance to succeed in China's provinces.

However, an empirical question arises: Did China's provinces with a smaller state sector speed up marketisation? This question is highly relevant given the fact that the Soviet republics with a large state sector had to undergo democratisation before embarking on liberal economic reform. If the answer is affirmative, we can conclude for sure that the size of the state sector is indeed the key to explaining smoother marketisation in China's provinces than in the Soviet republics and can help explain the contrasting reform courses in the Soviet Union and China. The above explanation of the China-Soviet contrast will then be confirmed.

\section{Provincial Promotion of Non-state Economy in China}

In order to assess the relationship between the size of the state sector and the pace of reform in China, the rate of economic reform in China's provinces must be evaluated. However, as ratings of economic reform in China's provinces are non-existent, I have decided, for reasons to be explained, to focus on provincial promotion of the non-state economy as an important aspect of local marketisation as well as a good measure of provincial reform.

Non-state sectors composed of collective firms (owned by local communal or political groups and dominated by rural enterprises), foreign-owned or joint ventures, private business, and mixed sectors. These non-state sectors are subject to more effective oversight by their owners and are thus more cost-effective than state firms; they have to survive increasingly tense market competition while enjoying little governmental protection; and they are more dynamic than state firms. ${ }^{27}$ This point is illustrated in Table 4.

Much of the phenomenal growth in China during the reform comes from non-state sectors. As Figure 2 shows, China's industrial output grew by over fivefold during the 1978-1997 period, from under 500 billion yuan to nearly 3,000 billion yuan (at 1978

price). Over half of the growth came from the rapidly expanding non-state sectors. The promotion of the non-state economy is thus a crucial reform measure in China. 
Table 4. Forms of Ownership in China in the Reform Era

Ownership Owners

National, provincial, and municipal

STATE
Level of Exposure

to Markets

\section{NON-STATE}

Townships, villages, local organisations and

Collective groups, and urban neighborhood committees

Private Individuals High

International investors or along with Chinese

Foreign collaborators

High

Figure 2. China's Industrial Output by Ownership, 1978-1997

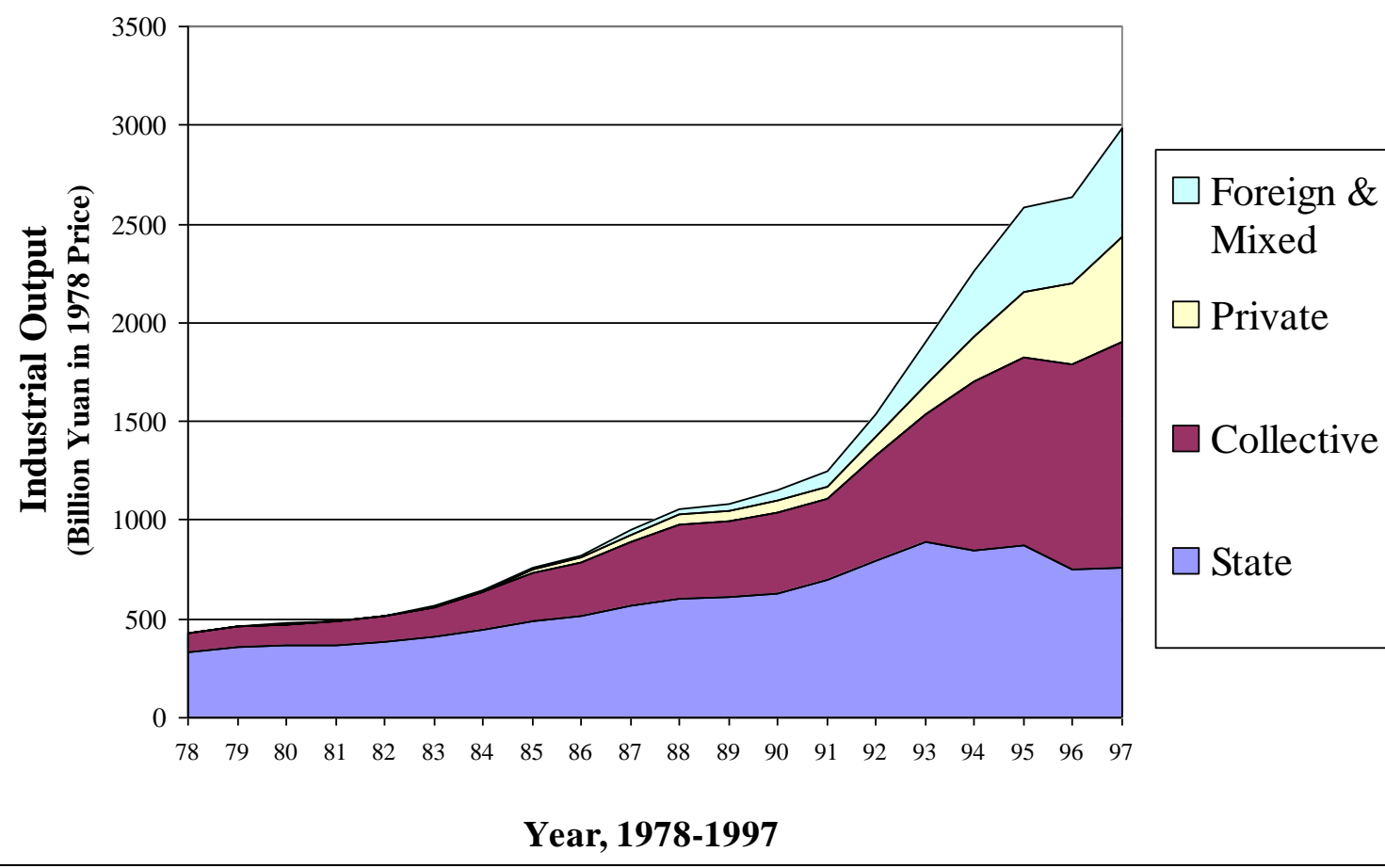


In the reform era, the central government and national reformists head by Deng devolved economic power to the localities partly to gain local support for its national reform. ${ }^{28}$ Deng also promoted provincial leaders who excelled at engineering local reform and growth. With a strong support from national reformists such as Deng Xiaoping, Zhao Ziyang, and $\mathrm{Hu}$ Yaobang and in the wake of decentralisation, provinces earned considerable leeway in charting their own reform course. Liberal-oriented provinces utilised their expanded economic freedom, eagerly pursued reform and actively promoted the non-state economy. In contrast, conservative provinces adopted sluggish reform, tried hard to protect SOEs, and restricted non-state firms. The extent of the growth of the non-state economy thus serves as an important and primary measure of provincial reform efforts. In this article, the change in the share of the non-state economy in provincial industrial output (CHGNSI) is used as an indicator of provincial reform efforts.

The above analysis on reform in the Soviet republics uses the share of the state sector in labour force as an indicator of the size of the state sector. The share of the non-state sectors in non-agricultural labour force (NSSLF) is used as an indicator of the size of non-state sectors in China's provinces. ${ }^{29}$ It has also been suggested that much larger nonstate sectors would encourage faster reform in China's provinces. In order to investigate this hypothesis, I regress CHGNSI during the 1980-88 period on the NSSLF in 1980 in 27 provinces (excluding Tibet, Hainan and Gansu due to lack of data). The results are summarized in the following formula ( $\mathrm{t}$ score in parentheses).

CHGNSI $_{80-88}=.058+.516 \mathrm{NSSLF}_{80} ;$ adjusted $\mathrm{R}$ square $=0.204, \mathrm{~F}$ score $=7.67$. (2.0) (2.77)

Using an expanded data set, I ran a similar analysis. I regressed the change in the share of non-state sectors in provincial industrial output during the 1978-93 period on the share of non-state sectors in non-agricultural labour force in 1980. The results, described as follows, are also similar.

$\mathrm{CHGNSI}_{78-93}=.115+.942 \mathrm{NSSLF}_{80} ; \quad$ adjusted R square $=0.21, \quad$ F score $=7.99$.

The two formulae are statistically significant. They suggest that provinces with larger non-state sectors at the beginning of reform would promote the non-state economy more swiftly and more actively in the subsequent decade. Therefore, the results support the above hypothesis that China's reform has been smoother than the Soviet one because China's provinces had larger non-state sectors (i.e., a smaller state sector). Due to resistance to reform from a larger state sector, Soviet leaders conducted political reform in order to generate greater support for more thorough economic reform. In China, a smaller state sector meant weaker resistance to reform, allowing economic reform to start in a number of provinces and then spread to other provinces. The Chinese state felt little need to undergo democratisation for the sake of furthering marketisation. 


\section{Provincial Incentives to Promote Economic Growth}

The next question is why a larger non-state economy at the beginning of reforms could induce reform in China's provinces in the subsequent years. Several reasons stand out. First of all, in the reform era local economic growth had become vital sources for local governments to generate local revenue and finance local public goods. Through economic decentralisation the center also passed to local governments numerous tasks including schooling children, providing unemployment benefits and health care for employees of SOEs and governmental institutions, and building local roads. But the central government provided them very limited money. ${ }^{30}$ In order to finance these unfunded mandates, local governments try to expand the local economy and generate revenue. The local economy affects even local governmental revenue and local cadres' material benefits. $^{31}$ Non-state sectors, as stated, serve as an important engine for economic boom.

Second, in the wake of economic decentralisation local governments have large claims to fiscal surplus, especially that from rural enterprises. This further motivates local governments to promote these enterprises. As Oi and Whiting suggest, the right to local fiscal revenue can be regarded a form of special property rights. ${ }^{32}$ In the wake of economic decentralisation, localities could claim a large portion of fiscal surplus. These claims also stimulate local interests in promoting the non-state economy.

Third, many local enterprises, especially collective enterprises have close ties with local governments. Local governments have fiscal and political stakes in the health of these enterprises. They might even collude with enterprises to evade central taxes. ${ }^{33}$ Foreign and private business people also cultivate ties with local officials and try to earn favourable treatment for business expansion.

Fourth, the primary criterion for cadres' performance has also shifted from ideological confirmation to economic growth. Local wealth has become a stepping stone for official promotion and is a main source of official prestige. ${ }^{34}$

Fifth, incentives to promote the non-state economy, however, are weaker in provinces with a larger state sector. Liberal policies were new to provinces and would entail risks. The entry of non-state enterprises could threaten the monopoly of SOEs, cut into the profits and taxes of SOEs, and even result in unemployment of SOEs. In provinces where SOEs were numerous and non-state enterprises were small, it would take a longer time for non-state enterprises to become a sizable player and significant fiscal contributor. In the short run, the negative impact of the liberalised entry of nonstate enterprises would be more apparent. In these provinces leaders and officials might be more reluctant to introduce reforms out of concern with poorer performance of the pillar sector (i.e. SOEs), economic disruption, and fiscal shortfalls. They might also worry about protests from workers who were laid off by SOEs under reform.

Finally, shorter tenure for jobs also accentuated worries of leaders of provinces with a large state sector about the short-term negative effects from expanding non-state sectors. The tenure for Party secretaries since 1979 averaged 3.44 years and that for governors 2.85 years. ${ }^{35}$ Meanwhile, within a 15-year span between 1978 and 1993 the share of non-state sectors in national industrial output rose by $31 \%$ (from $22 \%$ to 53\%). During a provincial leader's short tenure of three years, reformist policies might generate an average $6.2 \%$ gain for non-state sectors in the output. For provinces already with sizable non-state sectors, the gain might be larger than $6.2 \%$. For example, the share of non-state sectors in Zhejiang's industrial output registered a high 39\% in 1978 . From 
1978 to 1993 this share increased by $8 \%$ during every three years. The rapid gain thus helped these sectors to fast become the dominant player for the local economy. For the Northeastern Jilin Province that started with a small non-state sector which accounted for $21 \%$ of industrial output in 1978 , the share increased by merely $2.8 \%$ during every three years. Leaders of provinces with a larger state sector might adopt a risk-averse strategy of introducing cautious reforms. Therefore, provincial reform efforts would vary, depending on the size of non-state sectors at the onset of reform. ${ }^{36}$

\section{Advantages of Expanding Non-state Sectors in China}

The varying size of the state sector in China and the Soviet Union also shaped their subsequent strategies for marketisation. In the former Soviet republics, prior to 1990, the bureaucracy opposed any substantial reform of the central planning and SOEs and thwarted economic liberalisation. In the 1990s many former Soviet republics, especially Russia pushed for privatisation of SOEs through corporatisation, vouchers to citizens and even through sales of stocks to workers, managers, local governments and outside buyers. ${ }^{37}$ Privatisation, unfortunately, resulted in severe unemployment and a steep decline in consumption demands, hurting economic growth. It also degraded into asset stripping by managers and officials, or sales to workers of the enterprises under reform, and discrimination of common citizens (outsiders). However, the entry barrier for new non-state firms did not ease significantly under Gorbachev and probably even for years after the breakup of the Soviet Union. ${ }^{38}$ As a result, the economy is dominated by oligopolies of large former state enterprises, while dynamic non-state enterprises are deprived of their due roles.

In contrast, China's approach is liberalisation without privatisation. The state gradually relaxed entry of firms to the market while trying to improve the performance of SOEs and avoid mass sell-off of their assets. As stated, non-state firms have gradually grown into a dominant component of the economy and have become a main engine of China's growth. Meanwhile, some state enterprises have improved their performance after restructuring, while others are struggling. The state sector serves as a secondary engine for growth. Unemployment has risen, and yet it has not exploded. China has not experienced the same fall in consumption as did the former Soviet republics. China's gradual, pluralistic, and prudent approach to ownership reform helps sustain growth. All in all, the size of the state sector might help us to better account for the varying approach and outcomes in reform in these two large communist countries.

Booming non-state sectors have brought two significant benefits to China's provincial economy. The first benefit is that non-state sectors drove economic growth in provinces that were actively promoting these sectors. In provinces that endorsed these sectors and witnessed their rapid expansion, industrial output was growing also at a breakneck pace. In Zhejiang, for example, the share of non-state sectors in industrial output increased by 30\% from 1978 to 1988, far above the national average of $20.8 \%$. As a result, Zhejiang's annual industrial growth during the 1978-89 period registered $12.5 \%$, far higher than the national average of $9 \%$. The correlation coefficient between the 
change in the share of non-state sectors in industrial output during the 1978-88 period of twenty eight provinces whose data are available and the annual industrial growth during the 1978-89 period is 0.644 . Well exceeding the benchmark of 0.5 , this suggests that the two factors are highly correlated. In other words, the faster the boom of non-state sectors, the higher the growth these provinces would experience.

The second benefit of soaring non-state sectors is employment. Non-state sectors could provide jobs for rural surplus labor and urban job seekers, especially young laborers. Over the long run, non-state sectors have played a positive role in job creation, despite possible negative effects of competition against SOEs causing laid-offs in these enterprises. An analysis of regressing the average urban unemployment of the 1978-88 period (UNEMPL ${ }_{78-88}$ ) on change in the share of non-state sectors in industrial output of 78-88 $\left(\right.$ CHGNSI $\left._{78-88}\right)$ yields a statistical significance formula as follows: $\mathrm{UNEMPL}_{78-88}=$ $0.042-0.053 \mathrm{CHGNSI}_{78-88}$, adjusted $\mathrm{R}$ square $=0.10, \mathrm{~F}$ statistics of equation $=3.86$. Thus in the long run booming non-state sectors help to create jobs and ease urban unemployment, which in turn stimulates consumers' confidence, consumption and further economic growth. These two benefits can help to account for the stark contrast in the outcomes of reforms in the Soviet Union and China.

\section{Entrenchment and Maturation of the Command Economy}

In addition to the size of the state sector and reform initiatives at the sub-national level and national reform strategies, a second set of factors also contributed to the contrasts in China and Soviet reforms. Among them, a preeminent factor is that the planned economy was more entrenched and more developed in the Soviet Union than China. Specifically, the Chinese command economy was more rudimentary and operated more inefficiently than the Soviet counterpart. ${ }^{39}$ Thus it was easier and less costly for the Chinese to undertake reform.

These two factors may also explain the varying pace of economic reform in Asian and European ex-communist economies. The earlier the planned economy was set up, the more entrenched, developed and elaborate it would become, the greater the number of bureaucrats, managers, and employees who had a substantial stake in the system, and the greater the costs any overhaul of the system would incur. Central planning as an institution also follows the path of dependency. The longer it has existed, the greater inertia it would create to sustain itself.

In order to verify the role of institutional entrenchment in economic reform, I regress a measure of economic reform on the number of years under the command economy (YComEcn) in Asian and European ex-communist economies. These countries are China, Mongolia, Vietnam, Bulgaria, Czech Republic, Hungary, Poland, Romania, Slovak Republic, Slovenia, Estonia, Latvia, Lithuania, Albania, Croatia, Macedonia, Armenia, Azerbaijan, Belarus, Georgia, Kazakhstan, Kyrgyz Republic, Moldova, Russia, Tajikistan, Turkmenistan, Ukraine, Uzekistan. The measure is composed by the European Bank for Reconstruction and Development (EBRD), measuring the extent of economic reform. The aggregate transition indicator in 1999 (AgLibInx $\left.{ }_{99}\right)$ is the sum of scores on major economic reforms, including privatisation and restructuring, market liberalisation and competition, and financial markets reform. The higher the sore, the faster the reform a country had carried out. ${ }^{40}$ The regression result is as follows, with Tscores in parentheses. 
$\operatorname{AgLibInx}_{99}=2.08-1.05$ YComEcon; adjusted R square $=0.608, \quad$ F score $=42.92$.

(6.55) (-1.20)

The regression result suggests that the longer a country was under central planning the lower the index of its economic reform it would have, or the more conservative its reform would become. Thus, an entrenched command economy does indeed hinder reform. The Soviet people, as in the case of Russia, had lived under the command economy for 74 years when the economic reform started, and the Chinese did so for 29 years when Deng launched economic reform. The command economy was far more entrenched in the Soviet Union than in China and was more difficult to reform.

It has been argued that the Chinese economic planning was more rudimentary than the Soviet counterpart and was more susceptible to reform. This is indeed the case. Prior to reform the Soviet Central Statistical Administration (CSA) was more competent and effective than the State Statistical Bureau (SSB) in China. In 1959 the CSA already used national input-output tables with a 73-by-73 matrix. Only until 1982 did the SSB develop an 88-by-88 input-output table, yet it covered only one province. With a greater competency the Soviet central government allocated 48,426 products in 1973, but the Chinese counterpart only 617. A more rudimentary central planning makes reform of it easier, less costly, and more attractive for China; a more developed and mature central planning rendered its reformation more costly and less attractive in the USSR. ${ }^{41}$

In addition, as a result of a more entrenched and developed central planning, the central bureaucracy was larger in the Soviet Union than in China. In 1990, the employees of the central government in China including the Party totaled 340,000, or $0.06 \%$ of the nation's labour force. ${ }^{42}$ On the other hand, employees in the central government in the Soviet republics excluding those in the Ministries of Defence and Internal Affairs, the Central Party, and the Youth League accounted for $1.5 \%$ to $1.8 \%$ of the labour force in $1989 .{ }^{43}$ Thus an overhaul and weakening of central planning would jeopardise jobs of a much larger group of central governmental employees in the Soviet Union; these officials would have strongly opposed reform. In order to undermine the central opposition to his economic reform, Gorbachev resorted to democratisation and political decentralisation.

\section{Other Causes for Sino-Soviet Contrasts}

Another reason for greater difficulties for economic reform in the USSR than in China is that defense played a greater role in the economy and the state's revenue spending in the USSR. The Soviet Union spent a much greater sum than China on defence in order to match the U.S. military might, defend its extremely long border, and keep its Eastern Europe satellite countries under control. The U.S. government estimated that the USSR devoted 15 to $17 \%$ of its annual gross national product (GNP) to military spending since the mid-1980s and that until the early 1980s, Soviet defence expenditures rose between 4 and $7 \%$ a year. In 1988 when the military expenditure reached its peak it totalled US\$319 billion. $^{44}$

In contrast, China's defence spending was much smaller than that in the Soviet Union. Unlike the Soviets, the Chinese did not aim to match the U.S. military; it had a relatively shorter border to defend and had no major troop deployment in a satellite 
country. In the 1980s Deng even downsized the troops and cut the military budget in order to finance economic development. The U.S. Central Intelligence Agency estimated that the Chinese defence expenditures in 1978 absorbed 8 to $10 \%$ of GNP and that it fell within the range of 6 to $8 \%$ of GNP in 1986. In 1989 Chinese military spending totalled US $\$ 43$ billion, about one seventh of the Soviet expenses. ${ }^{45}$ China's military spending, measured in its share of the GNP, was about half of the size of the Soviet expenses.

A smaller defence industry benefited China's reform in two aspects. First, China could devote more resources for economic reform and ensure its success. Second, China did not have to reform a large defence industry that tended to be dominated by the state; China's economic reform was thus easier to implement.

In addition, a few factors also contribute to the China-Soviet contrasts in reform. First, Gorbachev's reform programmes, especially in the late 1980s, were impractical and even reckless. Even the Ryzhkov's gradual reform in July 1990 started with tripling of bread price, resulting in a veto by the USSR Supreme Soviet. Then this programme was replaced by the widely-noted "500 days" plan of Shatalin, which had an ambitious goal of abolishing central planning and building a market economy within 500 days. Yet it lacked specific and practical measures to address grave economic issues in reform. At the political front, as stated, Gorbachev erred disastrously in granting too much political power to republics and enabling them to break away from Moscow. ${ }^{46}$ The breakup of the union also dealt a devastating blow to the Soviet economy. One may attribute the radical and impractical reform in the Soviet Union to the Russian impatient and rash temperament and political idealism and the gradual and practical Chinese reform to the pragmatist Chinese political tradition upheld by Deng.

Another major factor is that historical junction at which the two nations started their reform. When China started its reform in the late 1970s, the party-state was in a deep legitimacy crisis and Mao's policies were widely discredited. After the tumultuous and traumatic Cultural Revolution, the Chinese sought an immediate improvement in their impoverished life. They were ready to accept a significant reversal of Mao's economic policies. $^{47}$ In contrast, the Soviet people had enjoyed a stable, decent albeit stagnant material life prior to reform. They feared about losses of their jobs, subsidies, and welfare in the course of reform. Therefore, it was easier to introduce economic reform in China than in the Soviet Union.

\section{Conclusion}

The contrast in the China-Soviet economic reform can thus in part be understood in terms of two sets of factors. The first is the size of the state sector in these two countries and subsequent reform strategies. Sizable non-state sectors and a relatively small state sector helped stimulate efforts in promoting marketisation in a number of China's provinces. With the support from paramount central reformist Deng Xiaoping, these liberal provinces gained an edge in reform and economic development, and their leaders obtained a ladder for fast political promotion. Other provinces were pressured to follow suit or risk losing out in an economic race in the long run. Thus competitive liberalization was generated. ${ }^{48}$ Chinese economic reform could proceed smoothly and spread across provinces without political liberalism. By avoiding political decentralisation, the central Party in China has maintained its administrative control of local officials and prevented them from rampantly plundering state assets. ${ }^{49}$ The success 
of economic reform earned the Chinese communist regime considerable political legitimacy and encouraged it to maintain its grip on power.

In contrast, the state sector was overwhelmingly large across the Soviet republics. Local reform initiatives were scant, whereas resistance to reform was strong. Gorbachev liberalised the political regime, generated popular support, and facilitated economic reform across the republics. This strategy proved to be disastrous. However, as many republics have a large majority of non-Russian population, ethnic separatism emerged in the wake of political decentralisation. As the Soviet Union disintegrated, the central government lost its ability to enforce effective and orderly economic reform and control official corruption, and economic catastrophes took place. Thus Sachs and Woo have rightly pointed to the varying size of the state sector as one of the causes of the ChinaSoviet contrast. ${ }^{50}$

A second set of causes also helps produce the divergence in China and Soviet reforms. The central planning was established earlier, in a more refined form, and more entrenched in the Soviet Union than in China. The defence industry and military spending were much larger in the Soviet Union than in China. In the late 1980s the Soviet leaders pursued a more radical, yet poorly-conceived reform package, resulting in setbacks of the reform. Finally, the Soviet people were more contented with economic policies than the Chinese prior to the reform. In contrast, the Chinese, who had suffered from the Cultural Revolution, desired a change in Mao's policies and a quick improvement in their living standard. The Chinese leaders emphasized pragmatism and incrementalism, avoiding major setbacks in reform. These factors combined to produce an easy start, smooth progress, and a quick success of economic reform in China; they rendered the launch of the Soviet marketisation more difficult, its progress more hazardous, and its success less likely.

\section{Notes}

\footnotetext{
${ }^{1}$ See Chen Kang, Gary H. Jefferson and Inderjit Singh, "Lessons from China's Economic Reforms," Journal of Comparative Economies, Vol. 16, No. 2 (June 1992), pp. 210-25; Alan Gelb, Gary Jefferson, and Inderjit Singh, "Can Communist Economies Transform Incrementally? The Experience of China," NBER Macroeconomics Annual (Cambridge: The MIT Press, 1993), pp. 87- 133; John McMillan and Barry Naughton, "How to Reform a Planned Economy: Lessons from China," Oxford Review of Economic Policy, Vol. 8, No. 1 (1993), pp. 130-43; Minxi Pei, From Reform to Revolution: The Demise of Communist in China and the Soviet Union. (Cambridge: Harvard University Press, 1994), pp. 87-133; Barry Naughton, Growing Out of the Plan: Chinese Economic Reform, 1978-93 (New York: Cambridge University Press, 1995); Joseph Stiglitz, "Whither Reform? Ten Years of the Transition," Proceedings of the World Bank Annual Conference on Development Economics 1999 (Washington D.C.: The World Bank, 2000); Yingyi Qian, "How Reform Worked in China," in Dani Rodrik (ed.), In Search of Prosperity: Analytical Narratives on Economic Growth (Princeton: Princeton University Press, 2003), pp. 297-333; Gerard Roland, Transition and Economics: Politics, Markets and Firms (Cambridge: The MIT Press, 2000), pp. 1-22, 131-196, 327-346.

${ }^{2}$ See David Lipton and Jeffrey Sachs, "Creating a Market Economy in Eastern Europe: The Case of Poland," Brookings Papers on Economic Activity, No. 1 (1990), pp. 75-147; Jeffrey D. Sachs, "The Transition at Mid Decade," American Economic Review, Vol. 86, No. 2 (May 1996), pp.128-33; Thomas
} 
A. Wolf, "The Lessons of Limited Market-Oriented Reform," Journal of Economic Perspectives, Vol. 5, No. 4 (Autumn 1991), pp. 45-58; Jan Winiecki, "Obstacles to Economic Reform of Socialism: A PropertyRights Analysis," Annals of the American Academy of Political and Social Science, Vol. 507 (January 1990), pp. 65-71; Andrei Schleifer and Robert W. Vishny, The Grabbing Hand: Government Pathologies and Their Cures (Cambridge: Harvard University Press, 1998), pp. 123-226; Anders Aslund, Building Capitalism: The Transformation of the Former Soviet Bloc (Cambridge: Cambridge University Press, 2002), pp. 348-395.

${ }^{3}$ See Joel S. Hellman, "Winners Take All: The Politics of Partial Reform in Postcommunist Transitions," World Politics, Vol. 50, No. 2 (January 1998), pp. 203-34.

${ }^{4}$ Refer to Yasheng Huang, "Information, Bureaucracy, and Economic Reforms in China and the Soviet Union," World Politics, Vol. 47, No. 1 (October 1994), pp. 102-34; Xinmin Pei, "Microfoundations of State-socialism and Patterns of Economic Transformation," Communist and Post-Communist Studies, Vol. 29, No. 2 (1996), pp. 131-45.

${ }^{5}$ See Jeffrey Sachs and Wing Thye Woo, "Reform in China and Russia," Economic Policy, Vol. 9, No. 18 (April 1994), pp. 102-45.

${ }^{6}$ See Anders Aslund, How Russia Became a Market Economy (Washington, D.C.: Brookings Institution, 1995), pp. 13-20.

${ }^{7}$ Steven L. Solnick, "The Breakdown of Hierarchies in the Soviet Union and China." World Politics, Vol. 48, No. 1, (January 1996), pp. 209-38.

${ }^{8}$ See Daniel Treisman, "Political Decentralization and Economic Reform: A Game-Theoretical Analysis," American Journal of Political Science, Vol. 43, No. 2 (April 1999), pp. 488-517. A comparative study of China and Hungary suggests that differing outcomes in the two countries could be traced to differences in the social costs of economic reform, the international environment, and elite strategies and coalitions. See Yanqi Tong, Transitions from State Socialism: Economic and Political Change in Hungary and China (Lanham and New York: Rowman \& Littlefield, 1997), pp. 1-19.

${ }^{9}$ See Philip G.Roeder, Red Sunset: The Failure of Soviet Politics (Princeton: Princeton University Press, 1993), p. ; and Aslund, How Russia Became a Market Economy, p. 28.

${ }^{10}$ Peter Rutland, The Politics of Economic Stagnation in the Soviet Union: The Role of Local Party Organs in Economic Management (Cambridge: Cambridge University Press, 1992), pp. 206-225.

${ }^{11}$ Linda J. Cook, The Soviet Social Contract and Why It Failed: Welfare Policy and Workers' Politics from Brezhnev to Yeltsin (Cambridge: Harvard University Press, 1994), chapter 1.

${ }^{12}$ Lipton and Sachs, "Creating a Market Economy in Eastern Europe," p. 100.

${ }^{13}$ Anders Aslund, Gorbachev's Struggle for Economic Reform (Ithaca: Cornell University Press, 1989), pp. ; Donna Bahry, "The Union Republics and Contradictions in Gorbachev's Economic Reform," Soviet Economy, Vol. 7, No. 3 (1991), pp. 213-55.

${ }^{14}$ For a detailed survey of Gorbachev's economic reform, refer to Ed A. Hewett and Victor H. Winston (eds.), Milestones in Glasnost and Perestroyka: The Economy (Washington, D.C.: Brookings Institution, 1991).

${ }^{15}$ See Donna Bahry, "The Union Republics and Contradictions in Gorbachev’s Economic Reform,” pp. 213-255.

${ }^{16}$ For a detailed survey of Gorbachev's political reform, refer to Ed A. Hewett and Victor H. Winston (eds.), Milestones in Glasnost and Perestroyka: Politics and People (Washington, D.C.: Brookings Institution, 1991).

${ }^{17}$ Anrey Sarkharov, "Interpretations and Perceptions of Perestroyka," and Jerry Hough, "Politics of Successful Economic Reform," in Hewett and Winston (eds.), Milestones in Glasnost and Perestroyka: Politics and People, pp. 139-54 and 246-86.

${ }^{18}$ Refer to Jeffrey Hahn, "Development in Local Soviet Politics," in Alfred Rieber and Alvin Rubinstein (eds.), Perestroika at the Crossroads (Armonk: M.E. Sharpe, 1991), pp. 75-101; and Jeffrey Hahn, "Local Politics and Political Power in Russia: The Case of Yaroslavl," Soviet Economy, Vol. 7, No. 4 (1991), pp. $322-41$.

${ }^{19}$ See Hellman, "Winners Take All," p. 203-234.

${ }^{20}$ Astrid Tuminez, "Nationalism, Ethnic Pressures, and the Breakup of the Soviet Union," Journal of Cold War Studies, Vol. 5, No. 4 (2004), pp. 81-136. 
${ }^{21}$ Ibid.,p.89-100; Philip G. Roeder, "Soviet Federalism and Ethnic Mobilization," World Politics, Vol. 43, No. 2. (January 1991), pp. 196-232; Steven L. Solnick, Stealing the State: Control and Collapse in Soviet Institutions (Cambridge: Harvard University Press, 1999), pp. 218-233.

${ }^{22}$ Solnick, Stealing the State, pp. 218-233.

${ }^{23}$ Alstair McAuley, "Economic Consequences of Soviet Disintegration," Soviet Economy, Vol. 7, No. 3 (1991), pp. 189-214.

${ }^{24}$ Colin Mackerras, China's Minorities: Integration and Modernization in the Twentieth Century (Hong Kong: Oxford University Press, 1994), pp. 139-166; Hongyi Harry Lai, "National Unity and Security in China's Western Development," Provincial China (forthcoming, 2005).

${ }^{25}$ Refer to Yasheng Huang, Inflation and Investment Controls in China: The Political Economy of CentralLocal Relations during the Reform Era (Cambridge: Cambridge University Press, 1996), pp. 89-126.

${ }^{26}$ State Statistical Bureau of China (SSB), Quanguo Gesheng, Zizhiqu, Zhixiashi Lishi Tongji Ziliao Huibian: 1949-89 (A Compilation of Historical Statistics of All the Provinces, Autonomous Regions, and DirectlyAdministered Metropolitans: 1949-89)(Zhengzhou: China Statistical Press, 1990), pp. 62-948.

${ }^{27}$ McMillan and Naughton, "How to Reform a Planned Economy," p. 132; Gelb, Jefferson, and Singh, "Can Communist Economies Transform Incrementally?" p.111.

${ }^{28}$ See Susan Shirk, The Political Logic of Economic Reform in China (Berkeley: University of California Press, 1993), pp.149-158.

${ }^{29}$ The size of the state sector (SSLF) can also be expressed as the share of the sector non-agricultural labour force. Expressed in a formula, NSSLF + SSLF $=1$. Therefore, a high NSSLF would mean a low SSLF. By measuring the size of the non-state sectors, we can also know about the size of the state sector.

${ }^{30}$ Christine Wong, Christopher Heady, and Wing T. Woo, Fiscal Management and Economic Reform in the People's Republic of China (Hong Kong: Oxford University Press, 1995), pp. 81-134. A study suggested that the central government granted provinces the freedom to undertake urban reform mainly to generate fiscal revenue. Refer to Hongyi Lai, "The Political Economy of China's Urban Reforms," presented at UCLA Graduate Student Conference, Ventura, California, October 28-29, 1999, posted at http://repositories.cdlib.org/asia.eslictme/chntrans02.

${ }^{31}$ Susan Whiting, Power and Wealth in Rural China: The Political Economy of Institutional Change (Cambridge: Cambridge University Press, 2001), pp. 72-120.

${ }^{32}$ See Jean Oi, Rural China Takes Off (Berkeley: University of California Press, 1999), pp.17-57; and Whiting, Power and Wealth in Rural China, pp. 121-175.

${ }^{33}$ Yasheng Huang, "Web of Interests and Patterns of Behavior of Chinese Local Economic Bureaucracies and Enterprises during Reforms," China Quarterly, No. 123 (September 1990), pp. 431-58.

34 See Whiting, Power and Wealth in Rural China, pp. 130-150; Zhiyue Bo, Chinese Provincial Leaders: Economic Performance and Political Mobility Since 1949 (Armonk: M.E. Sharpe, 2002), p. 115.

${ }^{35}$ Huang, Inflation and Investment Controls in China, p. 115.

${ }^{36}$ For a detailed study of inter-provincial differences in promoting the expansion of non-state sectors, refer to Hongyi Harry Lai, "The China Approach: Non-state Sectors and the Political Economy of Reform Strategies" (Singapore: unpublished manuscript, 2005), chapters 6-8.

${ }^{37}$ Oliver Blanchard, et al., Post-Communist Reform: Pain and Progress (Cambridge: The MIT Press, 1993), pp. 37-80.

Aslund, How Russia Became a Market Economy, pp. 28-31; Gelb, Jefferson, and Singh, "Can Communist Economies Transform Incrementally? pp. 28-31"; Roland, Transition and Economics; Schleifer and Vishny, The Grabbing Hand, pp. 123-182.

${ }^{39}$ See Huang, "Information, Bureaucracy, and Economic Reforms in China and the Soviet Union," pp.110117.

${ }^{40}$ International Monetary Fund, World Economic Outlook: October 2000 (Washington, D.C.: IMF, 2000), pp. 128-37.

${ }^{41}$ See Huang, "Information, Bureaucracy, and Economic Reforms in China and the Soviet Union," pp.124131; David Granick, Chinese State Enterprises: A Regional Property Rights Analysis (Chicago: University of Chicago Press, 1990), p. 73.

42 See Social Statistical Departments, SSB, Zhongguo Labor Tongji Nianjian 1991 (China Labour Statistical Yearbook 1991)(Beijing: Zhongguo Laodong Chubanshe), p. 294.

${ }^{43}$ See statistics in IMF, World Bank, OECD and EBRD, A Study of the Soviet Economy, (Paris: OECD, 1991), Vol. 1, pp. p. 198. 
${ }^{44}$ See "Russian Military Budget" at http://www.globalsecurity.org/military/world/russia/mo-budget.htm.

45 "Chinese Military Budget" at http://www.globalsecurity.org/military/world/china/mo-budget.htm.

${ }^{46}$ For a critical history of reform in the Soviet Union, refer to Stephen White, Handbook of Reconstruction in Eastern Europe and the Soviet Union (Harlow: Longman Group, 1991), pp. 205-56.

${ }^{47}$ Elizabeth Perry and Christine Wong (eds.), The Political Economy of Reform in Post-Mao China (Cambridge: Harvard University Press, 1985), pp. 2-3.

${ }^{48}$ Dali Yang, Beyond Beijing: Liberalization and the Regions in China (London: Routledge, 1997), pp. 4361.

${ }^{49}$ See Huang, Inflation and Investment Controls in China, pp. 350-329.

${ }^{50}$ Refer to Sachs and Woo, "Reform in China and Russia," pp. 102-145. 